\title{
In the Pursuit of Conceptualizing a Sustainable Human Development Index in a Globalized World: An Analysis of the Evidence from Assam and Meghalaya.
}

\section{En la búsqueda de conceptualizar un índice de desarrollo humano sostenible en un mundo globalizado: un análisis de la evidencia de Assam y Meghalaya.}

\begin{abstract}
Ayan Rudra
PhD Student, International Institute for Population Sciences, Mumbay, India, email: ayanrudra@gmail.com

\section{ABSTRACT}

There is worldwide consensus today that problems relating to the environment have reached immense proportions and that immediate drastic steps should be taken by nations and the global authorized community to arrest the decline of our environment. The World Health Organization estimates that roughly 25 percent of the disease burden in the developing world is due to environmental factors. For the purpose of this paper Environmental Human Development Index (EHDI) has been measured, which is a modified version of Human Development Index (HDI) in the pursuit of Conceptualizing a Sustainable Human Development Index in a Globalized World on the basis of Evidence from Assam and Meghalaya. This study is totally based on secondary data obtained from multiple sources. These are like- Census 2011, Central Pollution Control Board, India stat, World Bank, etc. The paper concludes with policy implications for the topic at hand. This study tries to search for development situation regarding environmental condition of two sister states of North East India. After including the environmental parameters and household status, the condition of development index is changing. Both states are increasing the development index value. But here Meghalaya increased its development value more than the state Assam. This study portrays with increasing environmental pollutants of particular state morbidity, especially cardiac diseases are increasing.
\end{abstract}

Keywords: Environment, Sustainable development, Human Development Index, Environmental Human Development Index, Air Pollution, cardio-disease.

RESUMEN 
Hoy existe un consenso mundial de que los problemas relacionados con el medio ambiente han alcanzado proporciones inmensas y que las naciones y la comunidad global autorizada deben tomar medidas drásticas inmediatas para detener el deterioro de nuestro entorno. La Organización Mundial de la Salud estima que aproximadamente el 25 por ciento de la carga de enfermedad en el mundo en desarrollo se debe a factores ambientales. Para el propósito de este documento, se midió el Índice de Desarrollo Humano Ambiental (EHDI), que es una versión modificada del Índice de Desarrollo Humano (IDH) en la búsqueda de Conceptualización de un Índice de Desarrollo Humano Sostenible en un Mundo Globalizado sobre la base de la Evidencia de Assam y Meghalaya. Este estudio se basa totalmente en datos secundarios obtenidos de múltiples fuentes. Estos son: Censo 2011, Junta Central de Control de la Contaminación, estadísticas de India, Banco Mundial, etc. El documento concluye con implicaciones de política para el tema en cuestión. Este estudio intenta buscar una situación de desarrollo con respecto a la condición ambiental de dos estados hermanos del noreste de la India. Después de incluir los parámetros ambientales y el estado del hogar, la condición del índice de desarrollo está cambiando. Ambos estados están aumentando el valor del índice de desarrollo. Pero aquí Meghalaya aumentó su valor de desarrollo más que el estado de Assam. Este estudio retrata el aumento de los contaminantes ambientales de la morbilidad del estado particular, especialmente las enfermedades cardíacas están aumentando.

Palabras clave: Medio ambiente, Desarrollo sostenible, Índice de desarrollo humano, Índice de desarrollo humano ambiental, Contaminación del aire, cardiopatía.

\section{INTRODUCTION}

Climate change is a potentially catastrophic worldwide externality and one of the most world's problematic situations. Unevenness between the distribution of causes and effect is very high across countries and generations as well. Today environment knowledge or awareness is the major important issue in the earth system. Some components of this issue are global warming, Green House Gas emission, Sea level rise, biodiversity change, climate change, etc. Development is a changing process that comes with urbanization, globalization, industrialization, etc. But sometimes it has been seen that with the lacking of proper technology and skills the quality of environment became fragile and distorted (Marcia, 2012).

There is worldwide consensus today that problems relating to the environment have reached immense proportions, and that immediate drastic steps should be taken by nations and the global authorized community to arrest the decline of our environment. Ensuring a clean and healthy environment through effective environmental management will provide multiple benefits to society and the economy. Nearly one-fourth of all diseases and deaths 
are due to hazards from unhealthy and poor environments. Some pollution is the main responsible for such types of human error, like the pollution of air, water, soil, land, etc. Among them, air pollution has the extremely negative impact on human health and global environment (McSweeney et al., 2010).

Pollution: This type of pollution occurs when Suspended Particulate Matters and different noxious gases occur in the air. Smoke, ash, dust particles, etc. are major constituents of SPM and Sulphur and nitrogen-based compounds. Air pollution is an essentially urban and industrial phenomenon. Some may be found in the rural part mainly smoke from combustion of firewood for domestic cooking and heating and some from rural primary based industries.

Earth is covered by $70 \%$ of its area by water. But a major part of water is in various oceans and seas, which is saline in nature. And not fit for household (drinking and another daily usage) or agriculture or industrial purpose. So the amount of usable water is very less in the earth. With this much water, a human can fulfill their requirement. But now a day due to various anthropogenic activities and some natural reasons water became contaminated. And also for such types of activities, the volume of safe water is reducing. There are three major sources of water pollution. These are industrial waste, urban sewage and solid waste and agricultural pollutants. Unsafe water is the major sources of various types of human diseases. Though day by day development occurring in the country likes India due to lack of proper and adequate technology we are unable to control pollution (Novothy, 1994). A number of study shows that overall daily mortality increases as the concentration of small particles in the air rises. A significant excess of cardiovascular as well as respiratory deaths related to particulate pollution has been found (Seaton et, al. 1995).

Environment and its sustainability: Environment means the surroundings. The surrounding us constitute our environment are land, water, plants, animals, solid wastes and other things. Man and environment are closely intertwined with each other, to maintain a balance or equilibrium in nature. The environment can be grouped into internal and external. External environment conditions can further be subdivided into two groups, Physical and Social. In Physical conditions, including all objects, forces situations and relations of the physical world to which individuals are sensitive. The external environment includes social conditions, standards of living, institutional and cultural phenomena. In the history of the geographical concept, some school of thoughts and some approach arose to understand the man-environment relationship (Laczko and Aghazarm, 2009).

Sustainable development can be ensured only by protecting the environment and using the resources wisely. Poor people often depend on natural resources for their livelihood are the most affected by environmental degradation and natural disasters (fire, storms, 
earthquakes, etc.), whose effects are worsened by environmental mismanagement. Poor people also suffer from shortcomings in the built environment: whether in urban or rural areas, they are more likely to live in standard housing, lack basic services and be exposed to unhealthy living conditions (Pearce and Warford, 1993). Dense urban environments, especially those without ample sanitation, are of public health concern because they endorse disease epidemics like influenza. Health danger associated with population growth include emerging and re-emerging diseases, poor vector control, poor sanitation, water and food contamination, air pollution and natural disasters (Neiderud, 2015).

Human Development Index: "Human development is concerned with advancing the richness of human life, rather than the richness of the economy in which human beings live." - According to Amartya Sen. Human development index developed and applied for the first time in 1990, is a tool to determine a nation region's attainment in the enrichment of human abilities (Wilkenfeld, 2015). The United Nation Development Program (UNDP) has developed a composite index, now this index known as Human Development Index. According to Human Development Report, 2006 - "The HDI is a summary measure of human development." So the HDI is a statistical tool used to measure a country's overall achievement in its social and economic dimensions and it is a process of extending human choices by enabling people to enjoy long healthy and creative lives by expanding human capabilities and functioning.

Historical Perspective of HDI: - Geographers, economists, and other social scientists have been taking an interest in human development. All the regions and ideologies have reached peaceful co-existence and discrimination to make life enjoyable and to increase the sustainability of the environment. According to United Nations- "Sustainable development is concerned with models of material consumption which are replicable while respecting cultural diversity." The basic components of Sustainable development are - Income, lifestyle, poverty, environment, social justice, population stability, etc (UN, 2001).

Background of the study area: Assam and Meghalaya are the most important states in North East India. Both are located south of the eastern Himalayas. The state of Assam is larger in the area having $78438 \mathrm{~km}$ square, while Meghalaya has $22429 \mathrm{sq}$. km. The latitudinal and longitudinal extension of Assam and Meghalaya are $25^{\circ} 02^{\prime} \mathrm{N}$ to $26^{\circ} 07^{\prime} \mathrm{N}$, $89^{\circ} 53^{\prime} \mathrm{E}$ to $92^{\circ} 58^{\prime} \mathrm{E}$ and $30^{\circ} 04^{\prime} \mathrm{N}$ to $28^{\circ} 00^{\prime} \mathrm{N}, 89^{\circ} 42^{\prime} \mathrm{E}$ to $96^{\circ} 00^{\prime} \mathrm{E}$ respectively. According to 2011 Census, Assam and Meghalaya state maintain 31169272 and 2964007 population and a population density of these states are $369.8 \mathrm{sq} . \mathrm{km}$. and $130.5 \mathrm{sq} . \mathrm{km}$. respectively. Assam has maintained more literacy rate $(76.3 \%)$ than Meghalaya $(72.2 \%)$, according to 2011 Census. The state Assam is facing some problems like illegal migration, flood, and unemployment, while Meghalaya suffering by violence, Jhum cultivation, political instability and illegal migration too. 
The main objectives of this study are: 1) To study the environment and sustainable economic development of Assam and Meghalaya: Constructing Sustainable Human Development Index. And 2) To explore the human health of Assam and Meghalaya in the context of human development and the environment.

\section{MATERIAL AND METHODS}

This study is totally based on secondary data obtained from multiple sources. These are like- Census 2011, Central Pollution Control Board, India stat and World Bank (Table 1).

To meet the first objective of this paper Environmental Human Development Index has been measured, which is a modified version of Human Development Index. And this is most authentic and reliable. Human Development Index measured with the help of GDP, life expectancy, and education. Some crucial factors like Household condition and environment status are always excluded. But to determine development Index these factors are very much important (Table 2).

HDI has been calculated with $1 / 3 *$ (GDP + education + life expectancy) as an accepted formula. However, EHDI will incorporate further essential components in terms of necessarily including an equal weight to Environmental factors and household facility as detailed below:

Environment Human Development Index $($ EHDI $)=1 / 5 *($ GDP + education + Life expectancy

+ household facility + environment factors).

GDP $=$ Per-capita Gross State Domestic Production

Education = Gross enrollment $($ primary + secondary + tertiary) + Adult literacy

Life Expectancy = lifetime expectation from birth

Household facility = Safe Drinking Water + Others (bathroom + latrine + waste water outlet)

Environmental factors $=\left(\mathrm{SO}_{2}+\mathrm{NO}_{2}+\mathrm{PM}_{10}\right)+$ Forest density

Here to determine the value of environmental factors highest and lowest values are taken from Indian highest and lowest level states. Like The highest and lowest forest density are Mizoram (90.68) and Rajasthan (4.7) respectively according to 2011 Census. Jharkhand emitted high $\mathrm{SO}_{2}(23 \mu \mathrm{g} / \mathrm{m} 3), \mathrm{NO}_{2}(39 \mu \mathrm{g} / \mathrm{m} 3)$ and $\mathrm{PM}_{10}(193 \mu \mathrm{g} / \mathrm{m} 3)$ and lowest observed in Kerala $\mathrm{SO}_{2}(4 \mu \mathrm{g} / \mathrm{m} 3), \mathrm{NO}_{2}(13 \mu \mathrm{g} / \mathrm{m} 3$

For analysing second objectives of this paper data like $\mathrm{SO}_{2}, \mathrm{NO}_{2}, \mathrm{SPM}$ (time series) data and some disease data like an Acute respiratory problem, Pneumonia, and Whopping a cough (these are highly sensitive disease due to air pollution) are taken. And different types of regressions are done like linear, polynomial and exponential regression. 
Sustainability, Agri, Food and Environmental Research, (ISSN: 0719-3726), 8(3), 2020: $205-218$ http://dx.doi.org/10.7770/safer-V0N0-art1990

$$
\begin{aligned}
& \text { Linear: } y=a+b_{x} \\
& \text { Exponential: } y=a+b . e
\end{aligned}
$$

Polynomial: $y=a+b_{x}+c_{x}$

\begin{tabular}{|c|c|c|c|c|}
\hline & & Variables & Assam & Meghalaya \\
\hline Life span & & Life Expectancy (year) & 63.6 & 65.5 \\
\hline Economy & & Per capita GDP (INR) & 25816 & 55371 \\
\hline \multirow[t]{4}{*}{ Education } & Gross & Primary (\%) & 81.5 & 99.9 \\
\hline & enrolment & Secondary (\%) & 65.7 & 83.6 \\
\hline & & Tertiary (\%) & 14.4 & 16.4 \\
\hline & & Adult literacy (\%) & 67.39 & 70.12 \\
\hline \multirow[t]{4}{*}{ Household } & Household & Safe drinking water (\%) & 79.51 & 67.48 \\
\hline & racmicy & Bathroom (\%) & 41.76 & 39.6 \\
\hline & & Latrine (\%) & 64.89 & 62.91 \\
\hline & & Waste water outlet (\%) & 20.4 & 35.27 \\
\hline \multirow[t]{4}{*}{ Environment } & Environmental & $\mathrm{SO} 2(\mu \mathrm{g} / \mathrm{m} 3)$ & 7 & 2 \\
\hline & 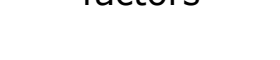 & $\mathrm{NO10}(\mu \mathrm{g} / \mathrm{m} 3)$ & 15 & 20 \\
\hline & & PM10( $\mu \mathrm{g} / \mathrm{m} 3)$ & 76 & 82 \\
\hline & & Forest density & 35.28 & 77.02 \\
\hline
\end{tabular}

Table 1. Sustainable human development indicators of Assam and Meghalaya (2011)

Table 2. Comparing EHDI between Assam and Meghalaya (2011)

\begin{tabular}{ccccccc}
\hline & $\begin{array}{c}\text { Life } \\
\text { expectancy }\end{array}$ & Education & GDP/capita & $\begin{array}{c}\text { Household } \\
\text { facility }\end{array}$ & $\begin{array}{c}\text { Environmental } \\
\text { factor }\end{array}$ & EHDI \\
\hline Assam & 0.643 & 0.621 & 0.226 & 0.511 & 0.511 & 0.521 \\
Meghalaya & 0.675 & 0.681 & 0.565 & 0.71 & 0.71 & 0.597 \\
\hline
\end{tabular}

Note: ${ }^{*}$ EHDI $=$ Environment Human Development Index 


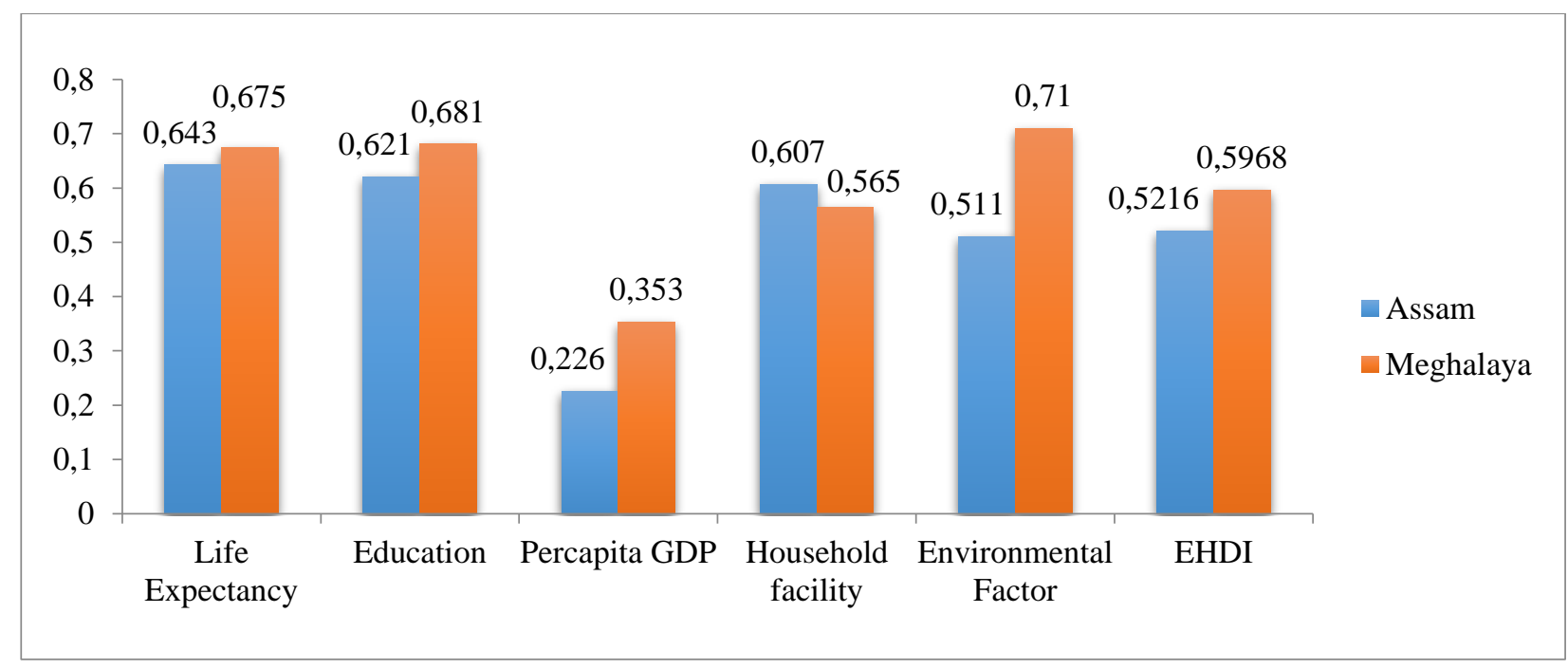

Fig 1. Environmental Human Development Index of Assam and Meghalaya.

\section{RESULTS}

Sustainable Human Development Index: The Word development implies acceptance of the limitations of the use of measures such as Gross National Product to measure the wellbeing of nations. The development embraces wider concerns of the quality of life- educational attainment, nutritional status, access to basic freedoms and spiritual welfare.

From the following diagram (Fig. 2), it is observed that, regarding situation development state Meghalaya is far better than Assam (except household facilities). According to Human Development Index Assam (0.491) is far behind than Meghalaya (0.563). But after including household and environmental parameters as sustainable development Assam and Meghalaya both has able to increase their status, but here Meghalaya (0.597) developed its status more comparing with Assam (0.521).

In every country water plays an essential role in development: from satisfying basic human needs, supporting agriculture, and providing sanitation services; to its role as a transport network and a key input in energy production and almost every type of industry. Without water, there can be no development. Poor sanitation and lack of access to safe drinking water are enormous problems in developing countries. The number of people lacking the above is rising, not falling. The lack of these facilities has enormous negative health and development implications for the developing world. Therefore it is very much essential to look state wise development value including the household condition in development index. 
Impact on Human Health by Various Pollutants: Human health continuously distorted at the receiving end as a result of the environmental degradation due to patchy and less systematic development. Areas exposed to toxic air pollutants can cause respiratory problems or dysfunctions like some chronic disease or asthma, pneumonia, etc. A huge number of people are known to have died off due to indirect effects of air pollution.

Health: Pollution of air as a result of man's activity has been a feature of the urban environment for centuries, probably since the introduction of fire as a means of heating and cooking. Urban air pollution increased with the use of wood and later coal for domestic heating and, later again, for industrial processes. Pollution arising from the latter was regarded for many years as a necessary or unavoidable evil, the inevitable price of the provision of work for the population. This paper has an association between air pollution and cardiovascular diseases (Pneumonia, Whopping a cough and acute respiratory problem), to consider whether the evidence is strong.

From Table 3 and 4 it is observed that some diseases like an acute respiratory problem, pneumonia and whooping cough which are very much sensitive to some environmental pollutants, these are increased over the period. These statuses were observed in both states. But the state Assam emitted more polluted gasses compared with Meghalaya emission. But Meghalaya emitted more per capita polluted gasses than Assam. Meghalaya emitted ten times more polluted gasses ( $\mathrm{SO}_{2}, \mathrm{NO}_{2}$ and $\left.\mathrm{SPM}\right)$ than Assam. As health Status Meghalaya emitted more per capita environment pollutant gasses than Assam, Meghalaya people are suffering more. From 2004 to 2011 people are suffering 4.91\% to $10.47 \%$ (Acute respiratory problem, pneumonia, and Whooping cough).

Table 3. Year wise showing some pollutants, population and forest cover of Assam

\begin{tabular}{ccccccccc}
\hline Year & $\mathrm{SO}_{2} *$ & $\begin{array}{c}\mathrm{NO}_{2} \\
* *\end{array}$ & $\begin{array}{c}\mathrm{SPM} \\
* * *\end{array}$ & Population & Forest (\%) & ARP & Pneumonia & $\begin{array}{c}\text { Whopping } \\
\text { Cough }\end{array}$ \\
\hline 2004 & 5.1 & 14 & 66.0 & 28020548 & 35.42 & 329092 & 10901 & 511 \\
2005 & 5.0 & 15.5 & 72.0 & 28475552 & 35.24 & 301192 & 11129 & 789 \\
2006 & 6.0 & 14.1 & 76.9 & 28930556 & 35.29 & 346782 & 11232 & 912 \\
2007 & 6.1 & 12.6 & 74.7 & 29385560 & 35.30 & 355414 & 35260 & 980 \\
2008 & 6.0 & 13.0 & 89.0 & 29840564 & 35.31 & 304214 & 30492 & 1109 \\
2009 & 7.0 & 15.0 & 88.0 & 30295568 & 35.30 & 355178 & 25095 & 1090 \\
2010 & 7.2 & 15.4 & 91.0 & 30750572 & 35.32 & 456547 & 24183 & 2180 \\
2011 & 7.3 & 15.8 & 96.0 & 31205576 & 35.28 & 514824 & 25816 & 1902 \\
\hline
\end{tabular}


Sustainability, Agri, Food and Environmental Research, (ISSN: 0719-3726), 8(3), 2020: 205-218 http://dx.doi.org/10.7770/safer-V0NO-art1990

Note: *Sulphur Dioxide, $* *$ Nitrogen Dioxide, $* * *$ Suspended Particulate Matter, $* * * *$ Acute Respiratory Problem $\left(\mu \mathrm{g} / \mathrm{m}^{3}\right)$. Sources: Indiastat.com and Census of India

Table 4. Year wise showing some pollutants, population and forest cover of Meghalaya

\begin{tabular}{ccccccccc}
\hline Year & $\begin{array}{c}\mathrm{SO}_{2} \\
*\end{array}$ & $\begin{array}{c}\mathrm{NO}_{2} \\
* *\end{array}$ & SPM*** & Population & $\begin{array}{c}\text { Forest } \\
(\%)\end{array}$ & ARP**** & Pneumonia & $\begin{array}{c}\text { Whopping } \\
\text { Cough }\end{array}$ \\
\hline 2004 & 5 & 19 & 71 & 2512381 & 75.4 & 120998 & 2312 & 202 \\
2005 & 4 & 15 & 79 & 2576899 & 75.74 & 168971 & 3011 & 658 \\
2006 & 4 & 17 & 84 & 2641417 & 76.47 & 173987 & 3580 & 981 \\
2007 & 3.1 & 21 & 83 & 2705935 & 77.22 & 219126 & 4857 & 1669 \\
2008 & 3 & 23 & 85 & 2770453 & 77.24 & 213692 & 5902 & 5358 \\
2009 & 3 & 20 & 87 & 2834971 & 77.24 & 312102 & 9224 & 1690 \\
2010 & 3 & 22 & 89 & 2899489 & 77.18 & 318124 & 9009 & 1128 \\
2011 & 3 & 24 & 95 & 2964007 & 77.19 & 295146 & 13601 & 1714 \\
\hline
\end{tabular}

Note: *Sulphur Dioxide, $* *$ Nitrogen Dioxide, $* * *$ Suspended Particulate Matter, $* * * *$ Acute Respiratory Problemc $\left(\mu \mathrm{g} / \mathrm{m}^{3}\right)$

Sources: Indiastat.com and Census of India.

The linear regression is between total pollution, and total diseases are very much significant and correlated with each other. The correlation value and significant value ( $p$ value) of Meghalaya are $0.916\left(R^{2}\right)$ and 0.001 respectively and Assam correlation and significant value ( $p$-value) are $0.876\left(R^{2}\right)$ and 0.013 respectively. Figures 2,3 and 4 showing that Assam emitted more polluted gasses but their cardio related health problems are very less over the period with comparing Meghalaya. But the main fact is that per capita emissions of such gasses are very high in Meghalaya than Assam. Meghalaya emitted $1.24 \mu \mathrm{g} / \mathrm{m}^{3}$ polluted gasses in 2004 to $1.358 \mathrm{\mu g} / \mathrm{m}^{3}$ polluted gasses in 2011 per 100000 populations, while Assam emitted $0.1 \mu \mathrm{g} / \mathrm{m}^{3}$ polluted gasses to $0.12 \mu \mathrm{g} / \mathrm{m}^{3}$ polluted gasses per 100000 populations in the same period. From this figures (2, 3 and 4 ), we can find out that human diseases are increased sharply with increasing different polluted gasses. 


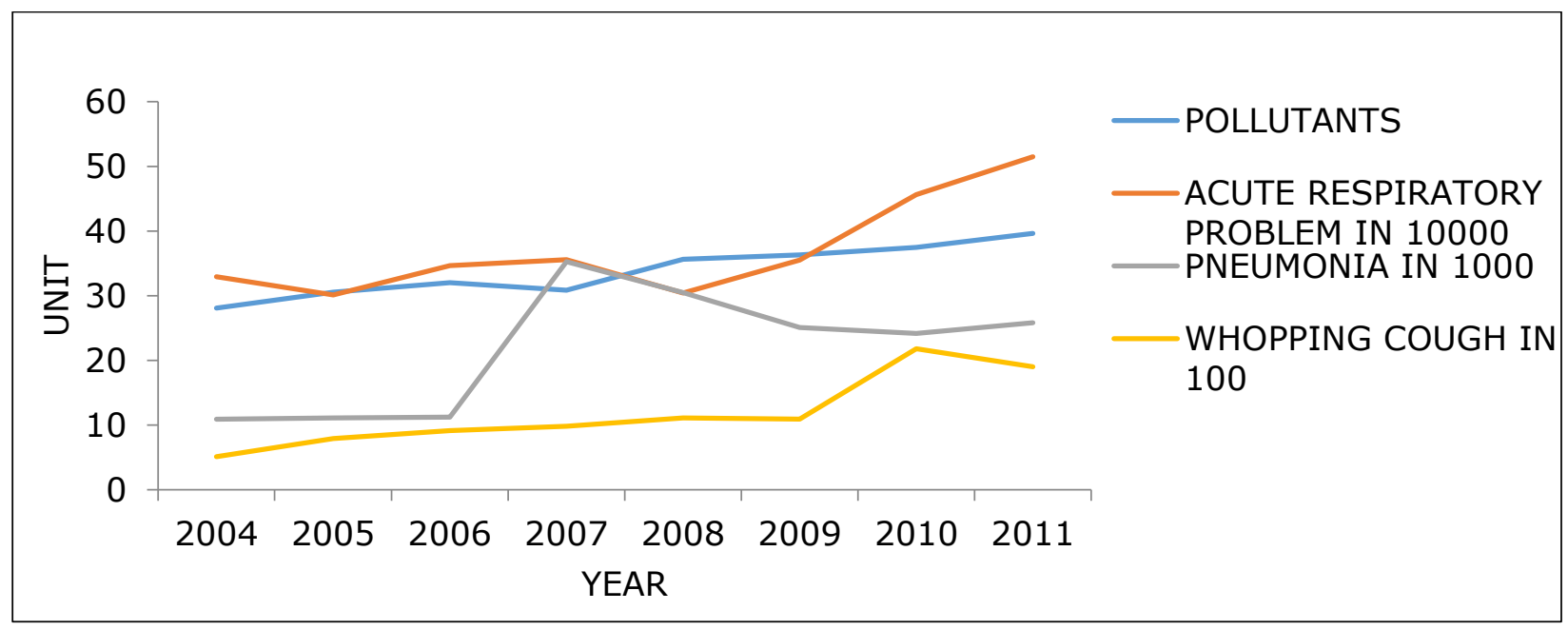

Fig 2. The trend line of Assam pollutants and some diseases

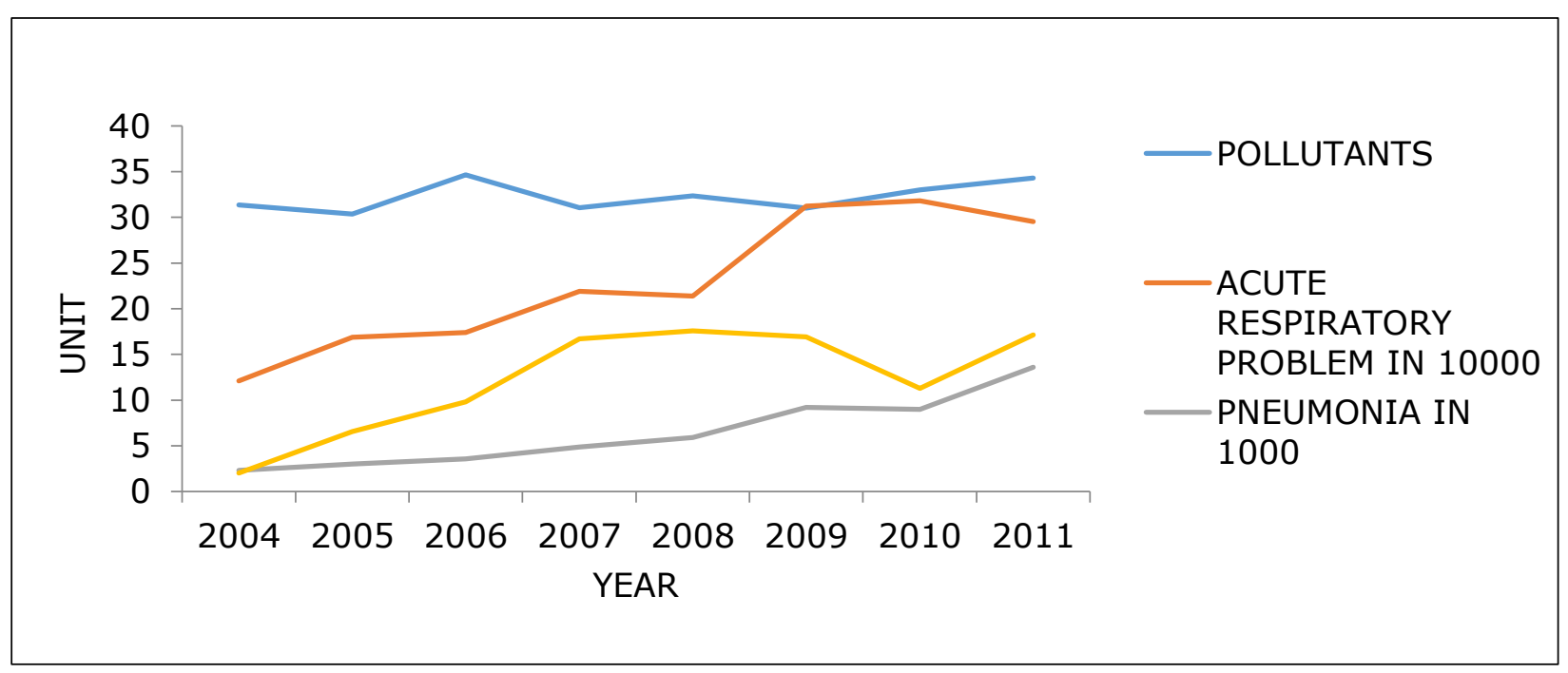

Fig 3. The trend line of Meghalaya pollutants and some diseases

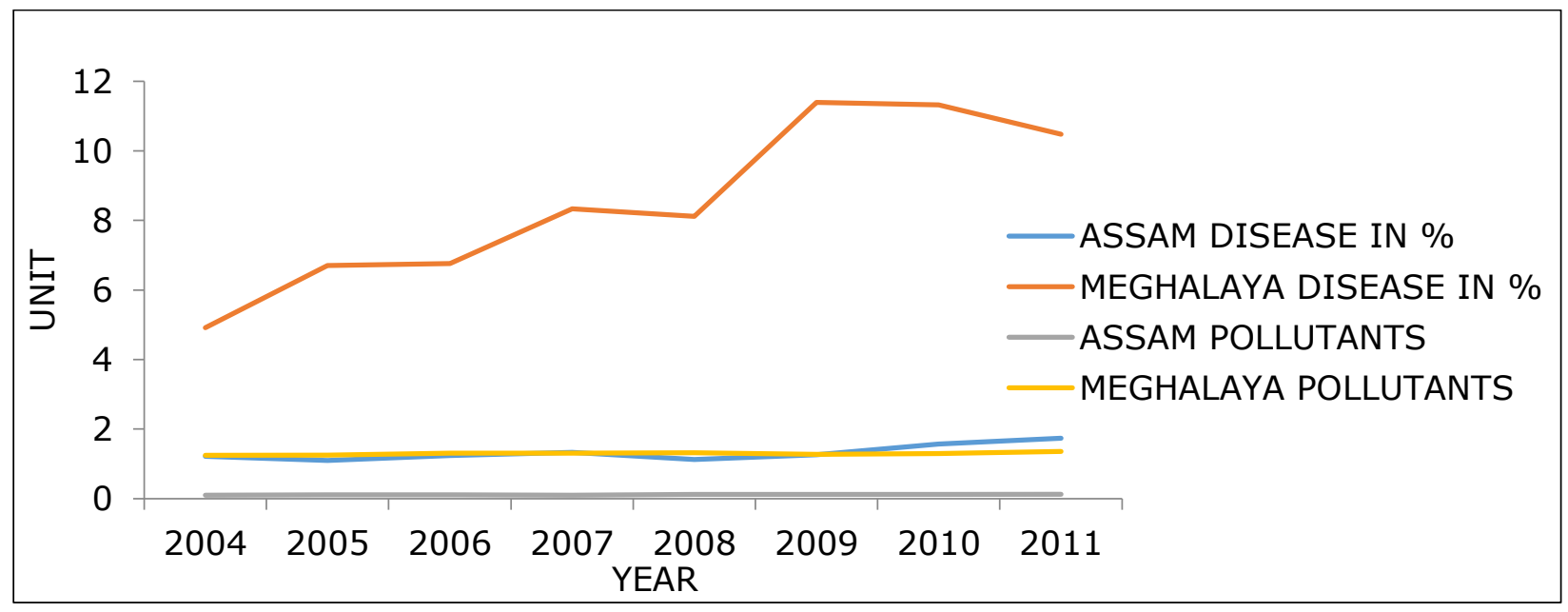

Fig 4. Correlation among different diseases and pollution of Assam and Meghalaya state 
$\mathrm{SO}_{2}$ : The trend $\mathrm{SO}_{2}$ of Assam increased in a very slow rhythm. In 2004 the $\mathrm{SO}_{2}$ emission was $5.1 \mu \mathrm{g} / \mathrm{m}^{3}$, but it increased to 7.3 in 2011 . But the trend is not linear sometimes it fluctuates. But in the case of Meghalaya within the period it is declining. This is also observed that in Assam SO 2 has sharply increased from 2009 to 2011 and the cases of an acute respiratory problem and whooping cough increase significantly in this particular time. Therefore, high correlation observed between this and $\mathrm{SO}_{2}$ emission. But in the case of Pneumonia, there is no positive correlation existing with $\mathrm{SO}_{2}$ emission in Assam. But Meghalaya state manages to control $\mathrm{SO}_{2}$ emission and also no significant relationship observed between $\mathrm{SO}_{2}$ emission and diseases.

$\mathrm{NO}_{2}$ : The state of Assam has increased $\mathrm{NO}_{2}$ emission from $14 \mu \mathrm{g} / \mathrm{m}^{3}$ in 2004 to 15.8 $\mathrm{\mu g} / \mathrm{m}^{3}$ in 2011 . But the increased rate is not smooth. It has been fluctuated significantly from 2006 to 2009, but after this time it has increased steadily. With the increase of $\mathrm{NO}_{2}$ emission in the atmosphere in this particular reference period, the cardio related diseases are also increased. But the significance level is not that much, as it found in the case of $\mathrm{SO}_{2}$. In the state of Meghalaya we also observed that different diseases are increased with increasing the emission of $\mathrm{NO}_{2}$.

SPM: The state of Assam emitting Suspended Particulate matter in an inclining way and also the same status has observed in the state of Meghalaya. But relatively Assam has emitted SPM more as compare to its counterpart. But in the case of per capita SPM emission, the atmosphere of Meghalaya polluted more than Assam. It has been observed that in the state of Assam, the relationship between pollution and different morbidities are very high, with high correlation and significant level ( $p$-value 0.009 and $R^{2}$ value 0.796 ). As like Assam, Meghalaya also has a high correlation with cardio relate diseases and pollution, where the $\mathrm{p}$ value is 0.005 and $R^{2}$ value is 0.867 .

As conclusion, this study tries to search environmental condition of two sister states of North East India. After including the environmental parameters and household status, the condition of development index is changing and both states are increasing the development index value. Meghalaya increased its development value relatively more than the state of Assam. But if Meghalaya manages to control these noxious gas emissions like $\mathrm{SO}_{2}, \mathrm{NO}_{2}, \mathrm{SPM}$ and tries to increase forest cover, then this state will be count as a developed state according to its development value. In case of Assam, this state has very low economic status, and environmentally it is well behind than Meghalaya (only $\mathrm{NO}_{2}$ emission is significantly less in Assam). So Assam needs to sharply increase its economic growth and also to take care of its environmental situation. Because when the less developed or developing nations are tried to increase their economic growth, they degrade their environmental status. So proper technology, skill, equipment are very much necessary to adopt for decreasing environmental 
degradation. And this paper also finds out the relationship between environmental gasses and some respiratory diseases (associated with air pollution). And it is found that $\mathrm{SO}_{2}, \mathrm{NO}_{2}$, and SPM gasses are increased and positively correlated over the period of time, which defines with increasing air pollution level cardio related diseases are also increasing.

As policy implications, the key environmental challenges that Assam and Meghalaya are facing related to the nexus of air pollution which accelerates environmental degradation. Economic growth is required for region, but it should maintain the ecology and environmental situations. Challenges are intrinsically connected with the state of environmental resources, such as land, water, air and their flora and fauna. Large scale of industrialization, the spread of transport communication, less recycling, wastage and other modern infrastructure combined with the pressures of population growth have added to the difficulties of preserving the clean environment and healthy natural resource base. And with the club of this status development index should be constructed, then it will be very much effective and ideal. And to achieve maximum development status government and the chief of the industrial sectors as well should take care of the polluted gas emission (from the different industry, vehicles and agriculture as well).

Globalization is needed for the development of any nation or region, but now government of Assam and Meghalaya should promote that structure which is economically feasible and environment-friendly. So without affecting the environment, government can fulfill the needs of the current generations without compromising that of the future generations and thereby make contributions to environment-friendly development.

\section{References}

Barik, S. K., \&Darlong, V. (2008). Natural resource management policy environment in Meghalaya impacting livelihood of forest poor.

(https://www.cifor.org/library/3104/natural-resource-management-policy-environment-inmeghalaya-impacting-livelihood-of-forest-poor/)

Beckerman, W. (1992). Economic growth and the environment: Whose growth? Whose environment?.World development, 20(4), 481-496.

Bohle, H. G., Downing, T. E., \& Watts, M. J. (1994). Climate change and social vulnerability: toward a sociology and geography of food insecurity. Global EnvironmentalChange, 4(1), 37-48.

Brook, R. D., Franklin, B., Cascio, W., Hong, Y., Howard, G., Lipsett, M., ...\&Tager, I. (2004). Air pollution and cardiovascular disease $A$ statement for healthcare professionals from 
the expert panel on population and prevention science of the American Heart Association. Circulation, 109(21), 2655-2671.

Frumkin, H. (2001). Beyond toxicity: human health and the natural environment.Americanjournal of preventive medicine, 20(3), 234-240.

Furie, G. L., \& Balbus, J. (2012). Global environmental health and sustainable development: the role at Rio+ 20. Ciencia\&saudecoletiva, 17(6), 1427-1432.

Geist, H. J., \&Lambin, E. F. (2002). Proximate causes and underlying driving forces of tropical deforestation: Tropical forests are disappearing as the result of many pressures, both local and regional, acting in various combinations in different geographical locations. BioScience, 52(2), 143-150.

Intergovernmental Panel on Climate Change. (2015). Climate change 2014: mitigation of climate change (Vol. 3). Cambridge University Press.

Jean-Yves, H., \&Loïc, V. (2013). OECD Insights Economic Globalisation Origins and consequences: Origins and consequences. OECD Publishing.

Keeler, E., M. Spence, and R. Zeckhauser (1972), .The Optimal Control of Pollution., Journal of Economic Theory, 4: 19-34.

Laczko, F., \&Aghazarm, C. (2009). Migration, Environment and Climate Change: assessing the evidence. International Organization for Migration (IOM).

McSweeney, C., New, M., Lizcano, G., \& Lu, X. (2010). The UNDP Climate Change Country Profiles: Improving the accessibility of observed and projected climate information for studies of climate change in developing countries. Bulletin of the American Meteorological Society, 91(2), 157-166.

Marambio-Jones, C., \& Hoek, E. M. (2010). A review of the antibacterial effects of silver nanomaterials and potential implications for human health and the environment. Journal of Nanoparticle Research, 12(5), 1531-1551.

Marcia, M., (2012) Climate Change and Natural Disasters. Current Controversies, 247.

Neiderud, C. J. (2015). How urbanization affects the epidemiology of emerging infectious diseases. Infection ecology \& epidemiology, 5(1), 27060.

Novotny, V. (1994). Water quality: prevention, identification and management of diffuse pollution. Van Nostrand-Reinhold Publishers.

Panda, A. (2009). Assessing vulnerability to climate change in India. Economic andPolitical Weekly, 44(16).

Pearce, D. W., \&Warford, J. J. (1993). World without end: economics, environment, and sustainable development. Oxford University Press.

Pope, C. A., Burnett, R. T., Thurston, G. D., Thun, M. J., Calle, E. E., Krewski, D., \&Godleski, J. J. (2004). Cardiovascular mortality and long-term exposure to particulate air pollution epidemiological evidence of general path physiological pathways of disease. Circulation, 109(1), 71-77. 
Ravindranath, N. H., Rao, S., Sharma, N., Nair, M., Gopalakrishnan, R., Rao, A. S., ...\& Krishna, N. (2011). Climate change vulnerability profiles for North East India. Current Science, 384-394.

Sagar and A.D. and Najam, A. (1998) 'The Human Development Index: A Critical Review', Ecological Economics, 25, pp. 249-264.

Seaton, A., Godden, D., MacNee, W., \& Donaldson, K. (1995). Particulate air pollution and acute health effects. The lancet, 345(8943), 176-178.

Stern, N., Peters, S., Bakhshi, V., Bowen, A., Cameron, C., Catovsky, S., ...\&Edmonson, N. (2006). Stern Review: The economics of climate change (Vol. 30, p. 2006). London: HM treasury.

Streeten, P., Burki, J. S., Haq, M. U., Hicks, N., and Stewart, F. (1981) First Things First: Meeting Basic Human Needs in Developing Countries, Oxford University Press, New York.

Tiwari, A. K. (2011). Energy consumption, CO2 emission and economic growth: A revisit of the evidence from India. Applied Econometrics and International Development, 11(2), 192-206.

Tol, R. S. (2009). The economic effects of climate change. The Journal of EconomicPerspectives, 29-51.

United Nations. Division for Sustainable Development, Expert Working Group on Improving the Role of Government in the Promotion of Environmental Management Accounting, Austria. BundesministeriumfürVerkehr, \& Innovation und Technologie. (2001). Environmental management accounting procedures and principles. UN.

Wilkenfeld, J. (2015). Myth and Reality in International Politics: Meeting Global Challenges through Collective Action. Routledge.

Received: $05^{\text {th }}$ June 2019; Accepted: $31^{\text {th }}$ December 2019; First distribution: $31^{\text {th }}$ January 2020; Final publication: 01th September 2020. 
Sustainability, Agri, Food and Environmental Research, (ISSN: 0719-3726), 8(3), 2020: 205-218 http://dx.doi.org/10.7770/safer-VONO-art1990 